\title{
Ethynyl-Linked (Pyreno)pyrrole-Naphthyridine and Aniline-Naphthyridine Molecules as Fluorescent Sensors of Guanine via Multiple Hydrogen Bondings
}

\author{
Shao-Hung Lu, ${ }^{\dagger}$ Srinivasan Selvi, ${ }^{\dagger}$ and Jim-Min Fang $*, \dagger,+$ \\ Department of Chemistry, National Taiwan University, Taipei 106, Taiwan, \\ and The Genomics Research Center, Academia Sinica, Taipei 115, Taiwan \\ twfang@ntu.edu.tw
}

Received September 4, 2006

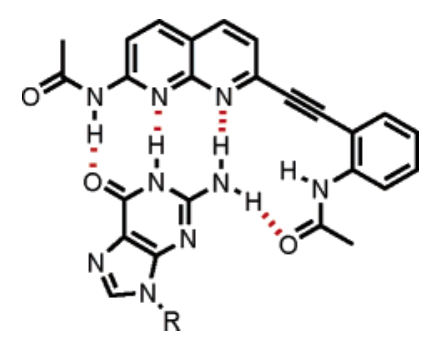

New fluorescent molecular sensors for 9-alkylguanines were constructed by conjugation of 2-acetamido1,8-naphthyridine with $N$-Boc-pyrrole, $N$-Boc-pyreno[2,1-b]pyrrole, or acetanilide moieties via an ethynyl bridge. In combination with the triple hydrogen-bonding motif of 2-acetamidonaphthyridine toward alkylguanine, an additional binding site was provided by the substituent properly located on the pyrrole or aniline ring to enhance the affinity of these receptor molecules. Besides the ESI-MS analyses, the binding events were readily monitored by the absorption and fluorescence changes in the visible region.

\section{Introduction}

Adenine (A), guanine $(\mathrm{G})$, cytosine $(\mathrm{C})$, thymine $(\mathrm{T})$, and uracil $(\mathrm{U})$ are the nitrogenous bases of DNA and RNA that play vital roles in the storage and transfer of genetic information. The Watson-Crick double helical structure of DNA is a result of the delicate interplay of the hydrogen bondings and the stacking of these nitrogenous bases. ${ }^{2}$ Hydrogen bonds between purine and pyrimidine bases of the two strands, e.g., $\mathrm{A}=\mathrm{T}$ and $\mathrm{G} \equiv \mathrm{C}$ pairs, are in complementary fashion to each other. Bulged and mismatch structures in nucleic acids arising from the nitrogenous bases that are not fully complementary to each other often lead to mutagenesis. ${ }^{1}$ These irregular DNA structures have been investigated theoretically and experimentally with the

* Address correspondence to this author. Fax: (886-2)-23637812. Phone: (886-2)-33661663.

$\dagger$ National Taiwan University.

\$ The Genomics Research Center.

(1) (a) Friedberg, E. C.; Walker, G. C.; Siede, W. DNA Repair and Mutagenesis; ASM Press: Washington, DC, 1995. (b) Ionov, Y.; Peinado, M. A.; Malkhosyan, S.; Shibata, D.; Perucho, M. Nature 1993, 363, 558561. (c) Streisinger, G.; Okada, Y.; Emrich, J.; Newton, J.; Tsugita, A.; Terzaghi, E.; Inouye, M. Cold Spring Harbor Symp. Quantum Biol. 1966, $31,77-84$. assistance of many artificial receptor molecules. ${ }^{2-6}$ Among them, 2-amino-1,8-naphthyridine derivatives have been shown to bind effectively with guanine derivatives via triple hydrogen bondings. ${ }^{3-6}$ To achieve high binding activity in a high selective fashion, the hydrogen-bonding sites in the receptor should be complementary with those in the guest molecules. Furthermore, 2-amino-1,8-naphthyridine in its dimeric and tetrameric forms is used to detect the guanine-guanine mismatches in DNA and guanine quartet in telomeres of chromosomes. ${ }^{4-5}$ Such detections are essential for identifying single nucleotide polymorphism and genetic mutations.

In the previous studies, ${ }^{5}$ characterizations of the binding events with guanine derivatives heavily relied on the measure-

(2) (a) Rebek, J., Jr.; Askew, B.; Ballester, P.; Buhr, C.; Jones, S.; Nemeth, D.; Williams, K. J. Am. Chem. Soc. 1987, 109, 5033-5035. (b) Zimmerman, S. C.; Weiming, W. J. Am. Chem. Soc. 1989, 111, 80548055. (c) Hosseini, M. W.; Blacker, A. J.; Lehn, J.-M. J. Am. Chem. Soc. 1990, 112, 3896-3904. (d) Furuta, H.; Magda, D.; Sessler, J. L. J. Am. Chem. Soc. 1991, 113, 978-985. (e) Rotello, V. M.; Viani, E. A.; Deslongchamps, G.; Murray, B. A.; Rebek, J., Jr. J. Am. Chem. Soc. 1993, 115, 797-798. (f) Inouye, M.; Takase, M. Angew. Chem., Int. Ed. 2001, 40, 1746-1748. (g) Okamoto, A.; Tainaka, K.; Saito, I. J. Am. Chem. Soc. 2003, 125, 4972-4973. (h) Wilds, C. J.; Maier, M. A.; Manoharan, M.; Egli, M. Helv. Chim. Acta 2003, 86, 966-978. (i) Abe, H.; Mawatari, Y.; Teraoka, H.; Fujimoto, K.; Inouye, M. J. Org. Chem. 2004, 69, 495-504. (j) Dohno, C.; Saito, I. ChemBioChem. 2005, 6, 1075-1081. 


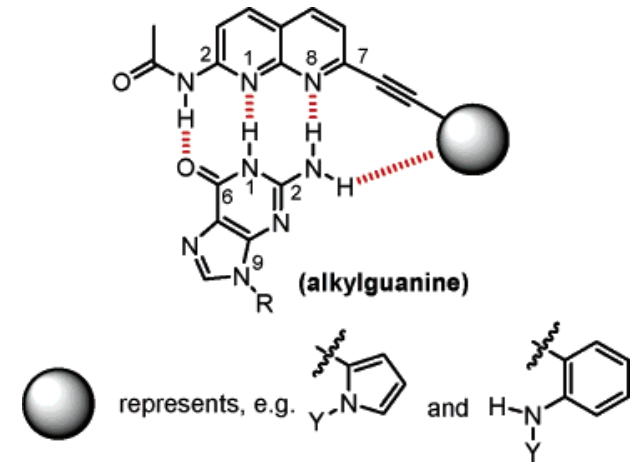

FIGURE 1. Putative 2-acetamido-1,8-naphthyridine derivatives having extended chromophore for quadruple hydrogen bondings with guanine.

ment of double helix melting temperature, the ${ }^{1} \mathrm{H}$ NMR analysis in solution, and the surface plasma resonance detection of immobilized substrate on the gold surface. In some examples, ${ }^{6}$ the binding of 2-amino-7-methylnaphthyridine (and its derivatives) with the target nitrogenous base at an abasic site in DNA duplex has been shown by the changes of fluorescence intensity. Fluorescence spectroscopy is a highly sensitive real time detection tool that has been extensively utilized in molecular recognition and biological research. Along this line, new naphthyridine-type fluorescent molecular sensors (Figure 1) can be designed for the guest molecule of guanine to address two major issues: (i) to incorporate an additional binding site into the existing triple hydrogen-bonding motif of 2-amino-1,8naphthyridine to intensify the binding affinity and (ii) to extend the conjugation of the 2-amino-1,8-naphthyridine structure to

(3) (a) Feibush, B.; Saha, M.; Onan, K.; Karger, B.; Giese, R. J. Am. Chem. Soc. 1987, 109, 7531-7533. (b) Hamilton, A. D. Chem. Commun. 1988, 765-766. (c) Murray, T. J.; Zimmerman, S. C. J. Am. Chem. Soc. 1992, 114, 4010-4011. (d) Bell, T. W.; Hou, Z.; Zimmerman, S. C.; Thiessen, P. A. Angew. Chem., Int. Ed. Engl. 1995, 34, 2163-2165. (e) Murray, T. J.; Zimmerman, S. C. Tetrahedron Lett. 1995, 36, 7627-7630 (f) Li, X.-Q.; Feng, D.-J.; Jiang, X.-K.; Li, Z.-T. Tetrahedron 2004, 60, 8275-8284. (g) Park, T.; Zimmerman, S. C.; Nakashima, S. J. Am. Chem. Soc. 2005, 127, 6520-6521. (h) Mayer, M. F.; Nakashima, S.; Zimmerman, S. C. Org. Lett. 2005, 7, 3005-3008. (i) Scherman, O. A.; Ligthart, G. B. W. L.; Sijbesma, R. P.; Meijer, E. W. Angew. Chem., Int. Ed. 2006, 45, 2072-2076.

(4) (a) Nakatani, K.; Okamoto, A.; Saito, I. Angew. Chem., Int. Ed. 1999, 38, 3378-3381. (b) Nakatani, K.; Sando, S.; Saito, I. J. Am. Chem. Soc. 2000, 122, 2172-2177. (c) Nakatani, K.; Sando, S.; Kumasawa, H.; Kikuchi, J.; Saito, I. J. Am. Chem. Soc. 2001, 123, 12650-12657. (d) Nakatani, K.; Sando, S.; Yoshido, K.; Saito, I. Bioorg. Med. Chem. Lett. 2001, 11, 335337. (e) Nakatani, K.; Sando, S.; Saito, I. Bioorg. Med. Chem. 2001, 9 , 2381-2385. (f) Nakatani, K.; Hagihara, S.; Sando, S.; Sakamoto, S.; Yamaguchi, K.; Maesawa, C.; Saito, I. J. Am. Chem. Soc. 2003, 125, 662666. (g) Nakatani, K.; Horie, S.; Murase, T.; Hagihara, S.; Saito, I. Bioorg. Med. Chem. 2003, 11, 2347-2353. (h) Sakamoto, S.; Nakatani, K.; Saito, I.; Yamaguchi, K. Chem. Commun. 2003, 788-789. (i) Nakatani, K.; Horie, S.; Saito, I. J. Am. Chem. Soc. 2003, 125, 8972-8973. (j) Nakatani, K.; Horie, S.; Murase, T.; Hagihara, S.; Saito, I. Bioorg. Med. Chem. 2003, 11, 2347-2353. (k) Peng, T.; Nakatani, K. Angew. Chem., Int. Ed. 2005, 44, 7280-7283. (1) Tok, J. B.-H.; Bi, L.; Saenz, M. Bioorg. Med. Chem. Lett. 2005, 15, 827-831. (m) Peng, T.; Murase, T.; Goto, Y.; Kobori, A.; Nakatani, K. Bioorg. Med. Chem. Lett. 2005, 15, 259-262.

(5) (a) Nakatani, K.; Kobori, A.; Kumasawa, H.; Saito, I. Bioorg. Med. Chem. Lett. 2004, 14, 1105-1108. (b) Nakatani, K.; Kobori, A.; Kumasawa, H.; Goto, Y.; Saito, I. Bioorg. Med. Chem. 2004, 12, 3117-3123.

(6) (a) Nishizawa, S.; Yoshimoto, K.; Seino, T.; Xu, C.-Y.; Minagawa, M.; Satake, H.; Tong, A.; Teramae, N. Talanta 2004, 63, 175-179. (b) Okamoto, A.; Saito, Y.; Saito, I. J. Photochem. Photobiol. C: Photochem. Rev. 2005, 6, 108-122. (c) Okamoto, A.; Tainaka, K.; Saito, I. J. Am. Chem. Soc. 2005, 127, 13128-13129.
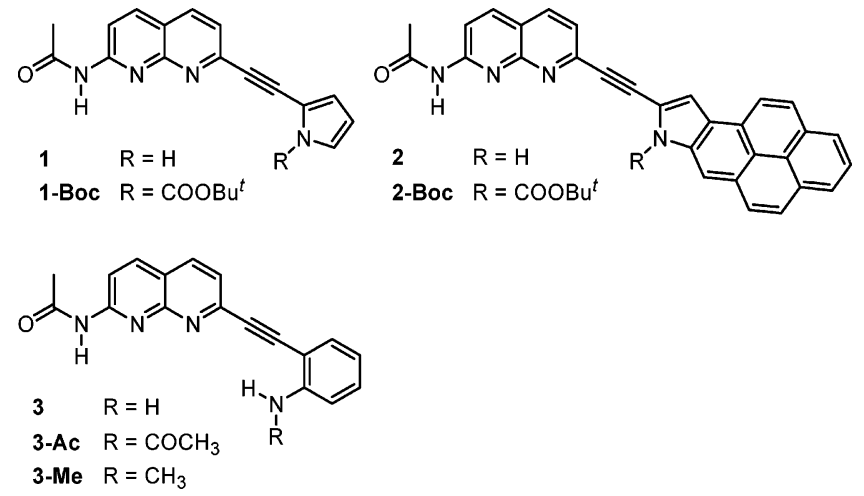

FIGURE 2. Receptor molecules designed for binding guanine with multiple hydrogen bondings.

build a chromophore that provides spectral changes preferably in the visible region for the real time detection of the binding event.

We have previously reported the push-pull molecules, e.g., 2,7-bis-(1H-pyrrol-2-yl)ethynyl-1,8-naphthyridine ${ }^{7}$ and 2,7-bis[N,N-di(2-hydroxyethyl)anilino] ethynyl-1,8-naphthyridine, ${ }^{8}$ having the core structure of naphthyridine conjugated with pyrrole or aniline moieties via ethynyl bridges. With the elongated conjugation, these receptor molecules are utilized to detect monosaccharides and mercury ion by the absorption and fluorescence changes in the visible region. We thus considered an approach to design guanine receptors (Figure 2) by incorporation of 2-acetamido-1,8-naphthyridine with an ethynyl linkage terminated by either pyrrole or aniline moieties. The idea is that coupling of pyrrole (or aniline) with 2-acetamido1,8-naphthyridine via an ethynyl linkage would result in an extended conjugation to cause the desired spectral red shifts, and the pyrrole (or aniline) moiety might act as an additional binding site for the $\mathrm{C} 2$ amino group of guanine. Upon binding with an incoming ligand of guanine, the receptor molecule might undergo conformational changes, so that the intramolecular charge transfer (ICT) at the excited state along with the rigidification effect of the receptor-ligand complex would cause significant spectroscopic changes. ${ }^{9}$

The synthesis of the ethynyl-linked pyrrole-naphthyridine and aniline-naphthyridine molecules was straightforward. The Sonogashira coupling reaction of 2-acetamido-7-chloro-1,8naphthyridine ${ }^{10}$ with 1-(tert-butoxycarbonyl)-2-ethynylpyrrole ${ }^{7}$ was carried out, using $\operatorname{Pd}\left(\mathrm{PPh}_{3}\right)_{2} \mathrm{Cl}_{2}, \mathrm{CuI}$, and $\mathrm{Et}_{3} \mathrm{~N}$ as the promoters, to afford compound 1-Boc in $52 \%$ yield. The Boc group in 1-Boc was removed by heating at $110^{\circ} \mathrm{C}$ in DMF to give a $78 \%$ yield of compound 1 . The receptor molecules 2 and 2-Boc were similarly synthesized, using a highly fluorescent

(7) (a) Liao, J.-H.; Chen, C.-T.; Chou, H.-C.; Cheng, C.-C.; Chou, P.-T.; Fang, J.-M.; Slanina, Z.; Chow, T. J. Org. Lett. 2002, 4, 31073110. (b) Fang, J.-M.; Selvi, S.; Liao, J.-H.; Slanina, Z.; Chen, C.-T.; Chou, P.-T. J. Am. Chem. Soc. 2004, 126, 3559-3566.

(8) Huang, J.-H.; Wen, W.-H.; Sun, Y.-Y.; Chou, P.-T.; Fang, J.-M. J. Org. Chem. 2005, 70, 5827-5832.

(9) (a) Lakowicz, J. R. Principles of Fluorescence Spectroscopy, 2nd ed.; Kluwer: New York, 1999; p 188. (b) Grabowski, Z. R.; Rotkiewicz, K.; Rettig, W. Chem. Rev. 2003, 103, 3899-4031. (c) McFarland, S. A.; Finney, N. S. J. Am. Chem. Soc. 2001, 123, 1260-1261. (d) Choi, K.; Hamilton, A. D. Angew. Chem., Int. Ed. 2001, 40, 3912-3915.

(10) (a) Newkome, G. R.; Garbis, S. J.; Majestic, V. K.; Fronczek, F. R.; Chiari, G. J. Org. Chem. 1981, 46, 833-839. (b) Corbin, P. S.; Zimmerman, S. C.; Thiessen, P. A.; Hawryluk, N. A.; Murray, T. J. J. Am. Chem. Soc. 2001, 123, 10475-10488. 


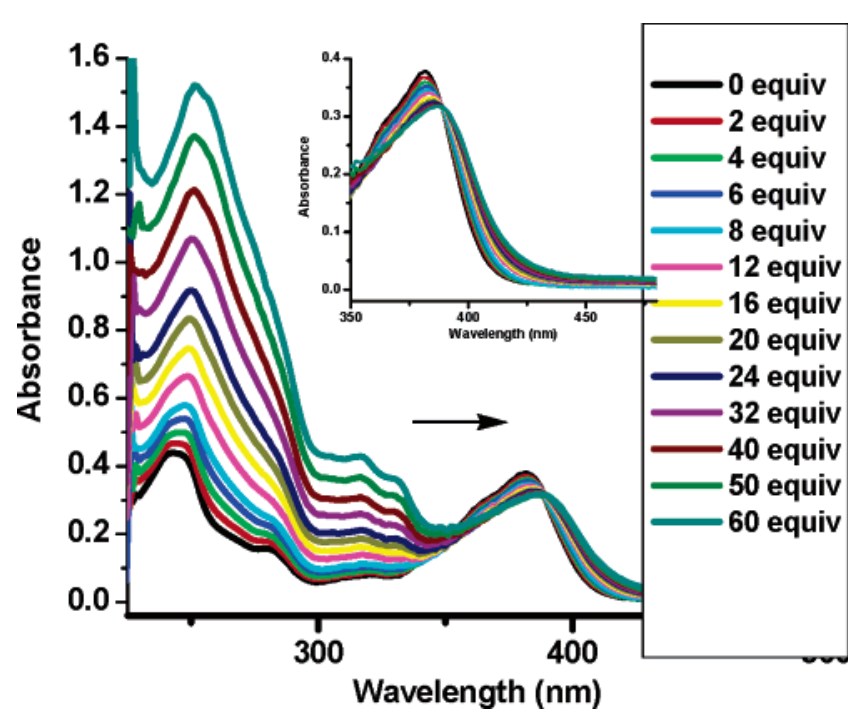

FIGURE 3. UV-vis titration of receptor $\mathbf{1}\left(1 \times 10^{-5} \mathrm{M}\right)$ upon addition of 9-octylguanine $\left(4 \times 10^{-3} \mathrm{M}\right)$ in $\mathrm{CH}_{2} \mathrm{Cl}_{2}$ solution.

chromophore of pyreno[2,1-b]pyrrole ${ }^{11}$ to replace the pyrrole unit. On the other hand, the Sonogashira coupling reaction of 2-acetamido-7-chloro-1,8-naphthyridine with 2-ethynylaniline and 2-ethynyl- $N$-methylaniline afforded respectively the ethynyllinked aniline-naphthyridine molecules $\mathbf{3}$ and $\mathbf{3}-\mathbf{M e}$ in $75 \%$ and $47 \%$ yields. Treatment of $\mathbf{3}$ with $\mathrm{Ac}_{2} \mathrm{O}$ in $\mathrm{Et}_{3} \mathrm{~N}$ gave the analogue 3-Ac.

Compounds 1 showed the absorption maximum at $382 \mathrm{~nm}$ in $\mathrm{CH}_{2} \mathrm{Cl}_{2}$ solution, and the fluorescence emission maximum at $460 \mathrm{~nm}$ upon excitation at $385 \mathrm{~nm}$. The large Stokes' shift $(\Delta \lambda=72 \mathrm{~nm})$ might be attributable to the ICT process, ${ }^{7,9}$ i.e., the $n, \pi$-electrons delocalization from the electron-donating pyrrole moiety to the electron-withdrawing naphthyridine center along the ethynyl bridge. Thus, the acidity of pyrrole and basicity of naphthyridine could be enhanced by the prominent ICT at the excited state. ${ }^{12}$ Upon titration of $\mathbf{1}$ with 9-octylguanine in $\mathrm{CH}_{2} \mathrm{Cl}_{2}$ solution, the resulting $\mathbf{1} \cdot$ alkylguanine complex exhibited only a slight red shift in the absorption spectra with $\lambda_{\max }$ at $388 \mathrm{~nm}$ (Figure 3). An isosbestic point in the absorption spectra supported that the equilibrium between the free receptor and the complex existed throughout the titration. While the emission wavelength did not show a considerable change during the titration, the fluorescence intensity did decrease gradually as the increments of octylguanine were added (Figure 4). On the basis of the changes of the fluorescence intensity, the association constant in $\mathrm{CH}_{2} \mathrm{Cl}_{2}$ solution was determined to be $5700 \pm 200 \mathrm{M}^{-1}$ at $298 \mathrm{~K}$ for the 1:1 complex of $\mathbf{1} \cdot$ octylguanine by means of the nonlinear least-squares curve fitting method ${ }^{13}$ (Table 1). The decreased fluorescence intensity might result from the energy loss in the relaxation process of the hydrogen-bonded 1·alkylguanine complex as that depicted in Figure 1.

By attachment of an electron-withdrawing tert-butoxycarbonyl group to the pyrrole moiety, the tendency for donating electrons from Boc-pyrrole to the ethynyl-naphthyridine moiety would be reduced. In comparison with $\mathbf{1}$, compound 1-Boc showed hypsochromic shifts in the absorption and emission

(11) Selvi, S.; Pu, S.-C.; Cheng, Y.-M.; Fang, J.-M.; Chou, P.-T. J. Org. Chem. 2004, 69, 6674-6678

(12) Chou, P. T.; Wu, G. R.; Wei, C. Y.; Cheng, C. C.; Chang, C. P.; Hung, F. T. J. Phys. Chem. B 2000, 104, 7818-7829.

(13) Connors, K. A. Binding Constants; Wiley: New York, 1987.

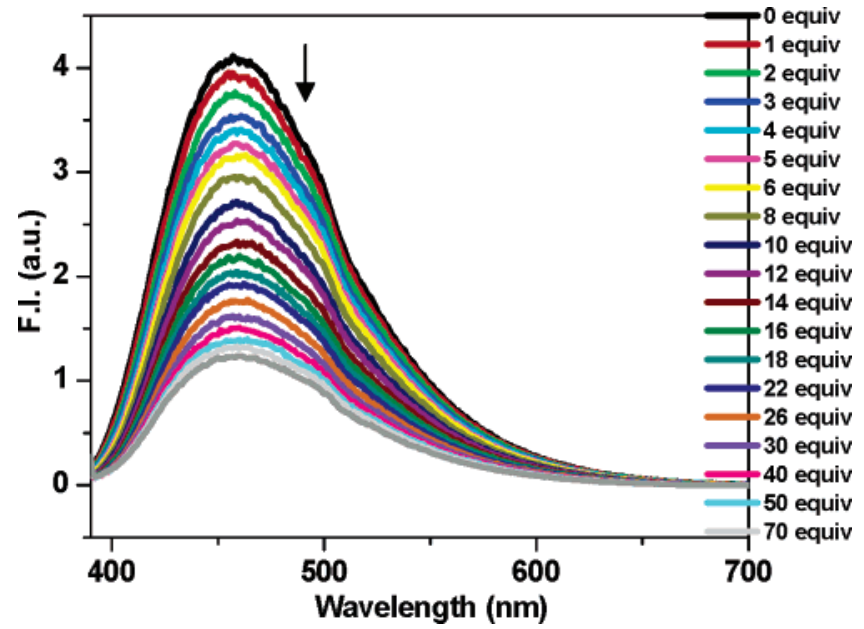

FIGURE 4. Fluorescence titration of receptor $1\left(1 \times 10^{-5} \mathrm{M}\right)$ upon addition of 9-octylguanine $\left(4 \times 10^{-3} \mathrm{M}\right)$ in $\mathrm{CH}_{2} \mathrm{Cl}_{2}$ solution. Excitation wavelength: $385 \mathrm{~nm}$.

spectra with the maxima at $378\left(\lambda_{\mathrm{abs}}\right)$ and $424 \mathrm{~nm}\left(\lambda_{\mathrm{em}}\right)$ in $\mathrm{CH}_{2^{-}}$ $\mathrm{Cl}_{2}$ solution. The titration of 1-Boc with 9-octylguanine showed the characteristic UV-vis and fluorescence spectral changes, i.e., the receptor-guanine complexation causing a red shift of absorption wavelength and a decrease of fluorescence intensity (see the Supporting Information). The absorption isosbestic point occurred at $384 \mathrm{~nm}$ throughout the titration, supporting the formation of a 1:1 complex. The binding constant for the (1Boc)•octylguanine complex was determined to be $13800 \pm 1300$ $\mathrm{M}^{-1}$ in $\mathrm{CH}_{2} \mathrm{Cl}_{2}$ solution (Table 1), about 2.5 times stronger than the association of $\mathbf{1} \cdot$ octylguanine complex.

The pyreno[2,1- $b]$ pyrrole moiety further extended the conjugation in molecules 2 and 2-Boc, so that their oscillator strengths increased to cause remarkable bathochromic shifts $(\sim 100 \mathrm{~nm})$ of fluorescence, in comparison with molecules $\mathbf{1}$ and 1-Boc, respectively. Upon addition of 9-octylguanine to $\mathbf{2}$ and 2-Boc in $\mathrm{CH}_{2} \mathrm{Cl}_{2}$ solutions, the fluorescence intensity decreased without change of the emission wavelengths $\left(\lambda_{\max }\right.$ at 549 and $522 \mathrm{~nm}$, see the Supporting Information). The association constants for the 1:1 complexes of $\mathbf{2} \cdot$ octylguanine and (2Boc) $\cdot$ octylguanine were determined to be $21700 \pm 1800$ and $63600 \pm 3800 \mathrm{M}^{-1}$, respectively (Table 1). The receptor molecules 1-Boc and 2-Boc bearing the tert-butoxycarbonyl group showed consistently higher affinity $(\sim 2.5$-fold $)$ toward alkylguanine than the Boc-free receptors $\mathbf{1}$ and $\mathbf{2}$, indicating the Boc group might lend itself to an additional hydrogen bonding with the 2- $\mathrm{NH}_{2}$ group of guanine. The molecular computation with the PM3 semiempirical method indicated that the $1 \cdot$ octylguanine complex contained triple hydrogen bondings with reasonable distances of $1.79-1.85 \AA$ between the 2 -acetamino-1,8-naphthyridine moiety of receptor $\mathbf{1}$ and the $\mathrm{C}=\mathrm{O}$ and $\mathrm{NH}$ groups of the guanine molecule (see the Supporting Information). The molecular modeling for the (1-Boc)-octylguanine complex also showed an additional hydrogen bonding exerted by the Boc group of 1-Boc and the 2- $\mathrm{NH}_{2}$ group of guanine with a distance of $1.86 \AA(\mathrm{C}=\mathrm{O} \cdots \cdot \mathrm{H}-\mathrm{N})$, in agreement with the higher binding strength of (1-Boc)-octylguanine complex over $1 \cdot$ octylguanine complex.

According to the fluorescence titrations, the receptor molecules 2 and 2-Boc also exhibited stronger affinity ( $\sim$-fold) over $\mathbf{1}$ and 1-Boc in binding with alkylguanine. This result might be attributable to the more effective conjugation in $\mathbf{2}$ and $\mathbf{2 - B o c}$ 
TABLE 1. Absorption, Fluorescence, and Binding Constants of Receptors and the Alkylguanine Complexes

\begin{tabular}{|c|c|c|c|c|c|c|}
\hline receptor & $\lambda_{\mathrm{abs}}(\mathrm{nm})^{a}$ & $\lambda_{\mathrm{em}}(\mathrm{nm})^{a}$ & complex & $\lambda_{\mathrm{abs}}(\mathrm{nm})^{a}$ & $\lambda_{\mathrm{em}}(\mathrm{nm})^{a}$ & $K_{\text {ass }}\left(\mathrm{M}^{-1}\right)^{b}$ \\
\hline 1 & 382 & 460 & $\mathbf{1} \cdot$ octylguanine & 388 & 460 & $5700 \pm 200$ \\
\hline 1-Boc & 378 & 424 & (1-Boc) octylguanine & 387 & 424 & $13800 \pm 1300$ \\
\hline 2 & 429 & 549 & 2.octylguanine & 431 & 549 & $21700 \pm 1800$ \\
\hline 2-Boc & 422 & 522 & (2-Boc) $)^{\circ}$ octylguanine & 425 & 522 & $63600 \pm 3800$ \\
\hline 3-Ac & 370 & 407 & $(\mathbf{3}-\mathbf{A c}) \cdot$ decylguanine & 368 & 407 & $64200 \pm 3800$ \\
\hline 3-Me & 399 & 518 & $(3-\mathbf{M e}) \cdot$ decylguanine & 402 & 535 & $91000 \pm 6000$ \\
\hline 5 & 401 & 527 & 5.octylguanine & 410 & 527 & $6600 \pm 300$ \\
\hline
\end{tabular}

${ }^{a}$ The maximum in $\mathrm{CH}_{2} \mathrm{Cl}_{2}$ solution. ${ }^{b}$ The binding constant measured in $\mathrm{CH}_{2} \mathrm{Cl}_{2}$ solution at $298 \mathrm{~K}$.

to cause a higher acidity at the pyreno[2,1-b]pyrrole moiety and a higher basicity at the naphthyridine moiety.

The ethynyl-linked aniline-naphthyridine molecules 3,3-Ac and 3-Me exhibited the absorption maxima at 377, 370, and $399 \mathrm{~nm}$, respectively, in the $\mathrm{CH}_{2} \mathrm{Cl}_{2}$ solutions. In comparison with $\mathbf{3}$, the electron-withdrawing acetyl group in molecule $\mathbf{3}$-Ac caused a small hypsochromic shift $(\Delta \lambda=7 \mathrm{~nm})$, whereas the electron-donating methyl group in molecule 3-Me induced a considerable bathochromic shift $(\Delta \lambda=22 \mathrm{~nm})$. While compound $\mathbf{3}$ was not fluorescent, 3-Ac and 3-Me emitted fluorescence in $\mathrm{CH}_{2} \mathrm{Cl}_{2}$ solutions respectively at $\lambda_{\max } 407(\Phi=0.078)$ and $518 \mathrm{~nm}(\Phi=0.005)$. The quantum yields $(\Phi)$ were measured by using a standard of 2,3,6,7,10,11-hexahydro$1 H, 5 H$-cyclopenta[3,4][1]benzopyrano[6,7,8-ij]quinolizin-12(9H)-one, known as coumarin 106. The emission spectra of 3-Ac and 3-Me were also solvent sensitive. The fluorescence wavelengths of 3-Me increased as the polarity of solvents increased, i.e., the emission maxima occurring at 500, 518, 544, 556, 558, and $565 \mathrm{~nm}$, respectively, in THF, $\mathrm{CH}_{2} \mathrm{Cl}_{2}, \mathrm{EtOH}$, $\mathrm{MeOH}, \mathrm{MeCN}$, and DMSO solutions. The fluorescence peak of 3-Ac also underwent bathochromic shifts as the polarity of the aprotic solvents increased, i.e., the emission maxima occurring at 393, 397, 407, 427, and $428 \mathrm{~nm}$, respectively, in EtOAc, THF, $\mathrm{CH}_{2} \mathrm{Cl}_{2}, \mathrm{MeCN}$, and DMSO solutions. It was noticed that molecule 3-Ac in $\mathrm{MeOH}$ showed the emission maximum at $436 \mathrm{~nm}$, even more red shift than in $\mathrm{MeCN}$ and DMSO with larger polarity scales. ${ }^{14}$ This phenomenon might be attributable to the external hydrogen bonding interactions of the protic solvent with the solute. $.^{9 a}, 14$

The binding of molecule $\mathbf{3}$ with 9-decylguanine was very weak; no apparent change in the UV-vis and fluorescence spectra was observed even with addition of excess amounts of decylguanine (e.g., 15 equiv). In contrast, compounds 3-Ac and 3-Me showed significant changes in the fluorescence spectra upon addition of 9-decylguanine in $\mathrm{CH}_{2} \mathrm{Cl}_{2}$ solution. Upon addition of decylguanine to 3-Ac, the fluorescence wavelength at $407 \mathrm{~nm}$ did not change; however, the formation of (3-Ac)-decylguanine complex caused a substantial decrease of the fluorescence intensity (see the Supporting Information). On the other hand, the fluorescence maximum of the free receptor 3-Me occurring at $518 \mathrm{~nm}$ was gradually shifted to $535 \mathrm{~nm}$ upon addition of decylguanine (Figure 5). On the basis of $1: 1$ stoichiometry, the apparent binding constants for the (3-Ac)-decylguanine and (3-Me)-decylguanine complexes were determined to be $64200 \pm 3800$ and $91000 \pm 6000 \mathrm{M}^{-1}$, respectively, from the fluorescence titrations at $298 \mathrm{~K}$ (Table 1). The quadruple hydrogen-bonded mode for the (3-Ac)-decylguanine complex was supported by a molecular computa-

(14) (a) Grabowski, Z. R.; Rotkiewicz, K.; Rettig, W. Chem. Rev. 2003, 103, 3899-4031. (b) Sun, Y.-Y.; Liao, J.-H.; Fang, J.-M.; Chou, P.-T.; Shen, C.-H.; Hsu, C.-W.; Chen, L.-C. Org. Lett. 2006, 8, 3713-3716.

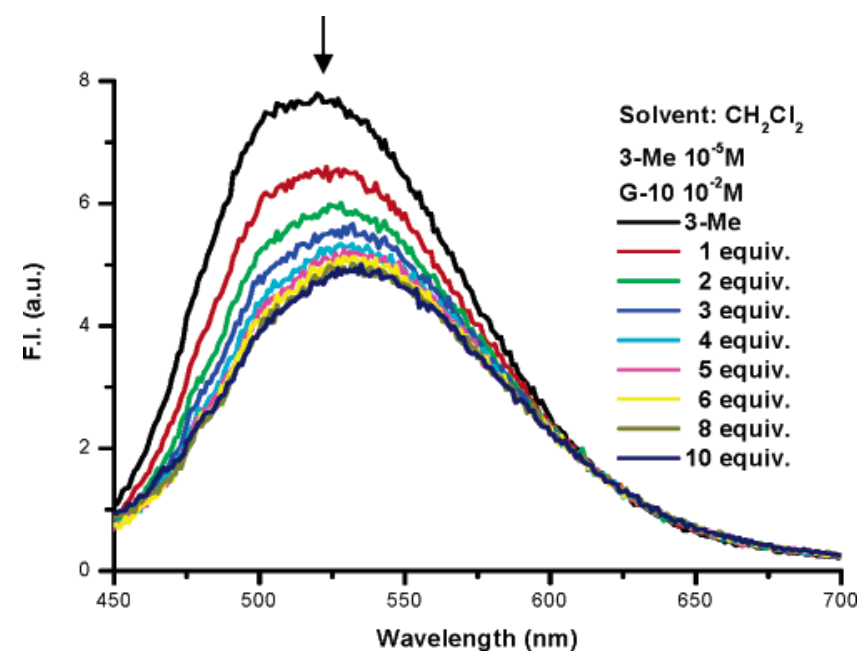

FIGURE 5. Fluorescence titration of receptor 3-Me $\left(1 \times 10^{-5} \mathrm{M}\right)$ upon addition of 9-decylguanine $\left(1 \times 10^{-2} \mathrm{M}\right)$ in $\mathrm{CH}_{2} \mathrm{Cl}_{2}$ solution. Excitation wavelength: $417 \mathrm{~nm}$.

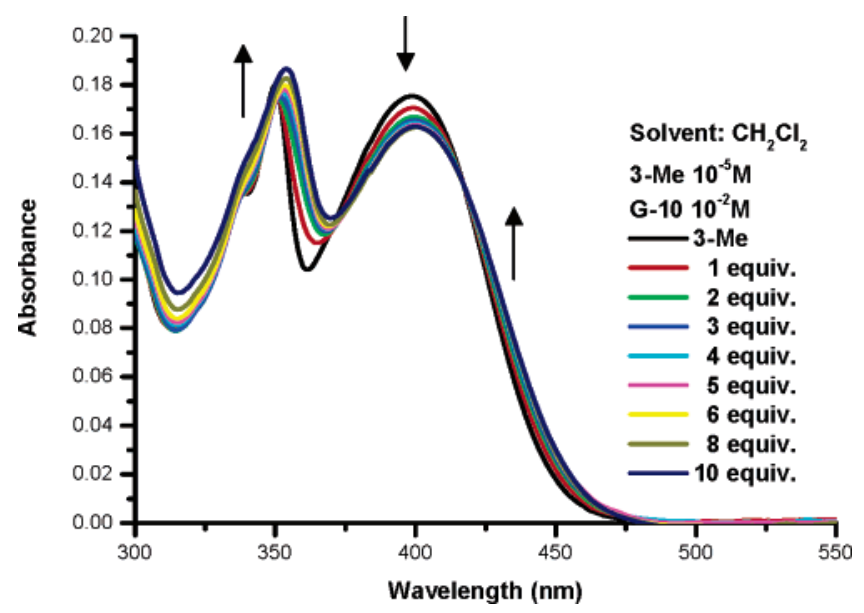

FIGURE 6. UV-vis titration of receptor 3-Me $\left(1 \times 10^{-5} \mathrm{M}\right)$ upon addition of 9-decylguanine $\left(1 \times 10^{-2} \mathrm{M}\right)$ in $\mathrm{CH}_{2} \mathrm{Cl}_{2}$ solution.

tion (see the Supporting Information). The electron-donating $N$-methylaniline moiety in 3-Me might be accounted for by the fluorescence red shift and the enhanced affinity with alkylguanine.

The UV-vis titration spectra of receptor 3-Me with 9-decylguanine in $\mathrm{CH}_{2} \mathrm{Cl}_{2}$ solution showed isosbestic points, indicating the equilibrium between the free receptor and the complex existed throughout the titration (Figure 6). The formation of the receptor-alkylguanine 1:1 complexes (3-Ac)-decylguanine and (3-Me) decylguanine was confirmed by the ESI-MS analyses, which showed the desired molecular ions at $\mathrm{m} / \mathrm{z}$ 636.3328 and 608.3450 for the protonated complexes (see the 
Supporting Information). The Job's plots based on the absorption changes in the titration curves also supported the 1:1 stoichiometry in the (3-Ac) -decylguanine and (3-Me)-decylguanine complexes (see the Supporting Information), though the somewhat visual offset from a mole fraction of $50 \%$ might be due to the solubility and aggregation of the receptor and alkylguanine.

The ${ }^{1} \mathrm{H}$ NMR studies were also attempted to obtain more evidence to support the proposed binding model (Figure 1). However, the NMR titrations failed (e.g., using 3-Me at $1 \times$ $10^{-3} \mathrm{M}$ ) due to the partial precipitation of decylguanine at higher concentrations (e.g., $\left.>5 \times 10^{-2} \mathrm{M}\right)$. We then prepared the analogous host and guest molecules 4, 4-Boc, 5, and 9-decyladenine for comparison studies.

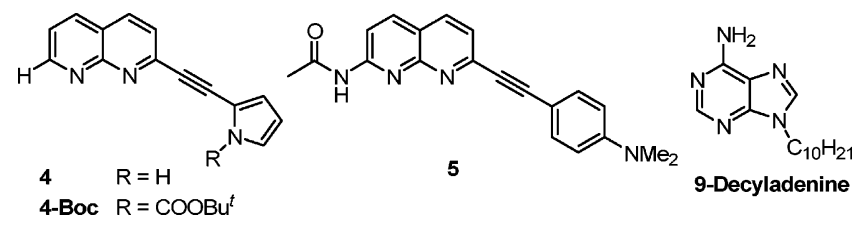

Unlike alkylguanine, the addition of 9-decyladenine to the $\mathrm{CH}_{2} \mathrm{Cl}_{2}$ solution of 3-Ac or 3-Me did not cause substantial changes in the UV-vis and fluorescence spectra. This result indicated that the ethynyl-linked aniline-naphthyridine molecules 3-Ac and 3-Me could not form complexes with adenine effectively via multiple hydrogen bonds. The conjugated pyrrole-naphthyridine molecules $\mathbf{4}$ and $\mathbf{4 - B o c}$, without the 2-acetamido group, were found to be insensitive to 9-octylguanine in the UV-vis and fluorescence titrations. Thus, the 2-acetamidonaphthyridine motif, which did not exist in $\mathbf{4}$ or $\mathbf{4 - B o c}$, acted as an essential part to provide the triple hydrogen bonding interactions with guanine (Figure 1).

Upon titration with 9-octylguanine in $\mathrm{CH}_{2} \mathrm{Cl}_{2}$ solution, the ethynyl-linked aniline-naphthyridine molecule $\mathbf{5}$ showed a decrease of fluorescence intensity, albeit in a relatively small degree. By monitoring the fluorescence changes at $527 \mathrm{~nm}\left(\lambda_{\max }\right)$ in the titration, the association constant for the $\mathbf{5} \cdot$ octylguanine complex was determined to be $6600 \pm 300 \mathrm{M}^{-1}$, about $10-$ 14-fold weaker than those of (3-Ac) octylguanine and (3-Me)-octylguanine complexes. While molecule 5 had a dimethylamino group at the remote para position, the acetamido and methylamino substituents at the ortho positions in molecules 3-Ac and 3-Me would be favorable to exert an additional interaction, synergistically with the triple hydrogen-bonding motif of the 2-acetamidonaphthyridine moiety, to enhance the binding with alkylguanine.

\section{Conclusion}

We have devised the guanine-binding molecules, e.g., 1-Boc, 2-Boc, 3-Ac, and 3-Me, based on the ethynyl-linked (pyreno)pyrrole-naphthyridine and aniline-naphthyridine scaffolds. The acetamidonaphthyridine moiety in these receptor molecules provided the hydrogen donor-acceptor-acceptor (DAA) motif to bind the guanine molecule with the complementary ADD motif of $\mathrm{O}=\mathrm{C}_{6}-\mathrm{N}_{1} \mathrm{H}-\mathrm{N}_{2} \mathrm{H}$ (Figure 1). The Boc and Ac groups in these receptor molecules likely exerted an additional interaction with the 2- $\mathrm{NH}_{2}$ group of guanine to enhance the formation of the quadruple hydrogen-bonded complexes. In contrast, the ethynyl-linked pyrrole-naphthyridine molecules 4 and 4-Boc lacked the 2-acetamido group for an effective binding with alkylguanine. The higher affinity of alkylguanine over alkyladenine in binding with 3-Ac and 3-Me was in agreement with the proposed multiple hydrogen-bonded model. In addition to the ESI-MS analyses, the binding events were readily monitored by the UV-vis and fluorescence spectroscopy. The extended conjugation of the ethynyl-linked (pyreno)pyrrolenaphthyridine and aniline-naphthyridine receptor molecules rendered sensitive and convenient fluorescence detection in the visible region. In comparison with the previously reported guanine-binding molecules, ${ }^{2-6}$ the ethynyl-linked (pyreno)pyrrole-naphthyridine and aniline-naphthyridine molecules showed comparable or better affinity toward guanine derivatives. The synthesis of 3-Ac and 3-Me was straightforward. Modification of the receptor molecules by introduction of other binding elements, preferably with hydrophilic property, to the acetyl and methyl groups should be doable. The ditopic receptor molecules prepared as such can be tested for sensing the biologically important guanine derivatives, e.g., nucleosides and nucleotides, in the physiologically compatible media. We are currently engaged in this endeavor.

\section{Experimental Section}

2-Acetamido-7-(1-tert-butoxycarbonylpyrrol-2-yl)ethynyl-1,8naphthyridine (1-Boc). To a solution of 2-acetamido-7-chloro1,8-naphthyridine ${ }^{10}(221 \mathrm{mg}, 1 \mathrm{mmol})$ in anhydrous THF $(5 \mathrm{~mL})$ was added $\mathrm{Et}_{3} \mathrm{~N}(1.73 \mathrm{~mL})$ followed by addition of $\mathrm{Pd}\left(\mathrm{PPh}_{3}\right)_{2} \mathrm{Cl}_{2}$ $(27.8 \mathrm{mg})$ and $\mathrm{CuI}(7.8 \mathrm{mg})$ under $\mathrm{Ar}$ at room temperature. The resulting mixture was left to stand at room temperature for $10 \mathrm{~min}$, and then 2-ethynylpyrrole-1-carboxylic acid tert-butyl ester ${ }^{7}$ (190 $\mathrm{mg}, 1 \mathrm{mmol})$ in THF $(5 \mathrm{~mL})$ was added dropwise. The resulting solution was stirred at room temperature for $24 \mathrm{~h}$. The volatiles were removed under reduced pressure. The residue was dissolved in $\mathrm{CH}_{2} \mathrm{Cl}_{2}$, passed through a short plug of Celite, and washed with EtOAc. The organic phase was evaporated to dryness, and then purified by flash column chromatography on silica gel with elution of $\mathrm{MeOH} / \mathrm{CH}_{2} \mathrm{Cl}_{2}$ (1:19) to give $196 \mathrm{mg}$ of compound 1-Boc $(52 \%$ yield).

$\mathrm{C}_{21} \mathrm{H}_{20} \mathrm{~N}_{4} \mathrm{O}_{3}$ : UV-vis $\lambda_{\max }\left(\mathrm{CH}_{2} \mathrm{Cl}_{2}\right) 378 \mathrm{~nm}\left(\epsilon=29000 \mathrm{M}^{-1}\right.$ $\left.\mathrm{cm}^{-1}\right) ; \mathrm{FL} \lambda_{\max }\left(\mathrm{CH}_{2} \mathrm{Cl}_{2}\right) 424 \mathrm{~nm} ;{ }^{1} \mathrm{H}$ NMR $\left(\mathrm{CDCl}_{3}, 400 \mathrm{MHz}\right) \delta$ $9.16(1 \mathrm{H}$, br s), $8.49(1 \mathrm{H}, \mathrm{d}, J=8.0 \mathrm{~Hz}), 8.13(1 \mathrm{H}, \mathrm{d}, J=8.0$ $\mathrm{Hz}), 8.05(1 \mathrm{H}, \mathrm{d}, J=8.0 \mathrm{~Hz}), 7.55(1 \mathrm{H}, \mathrm{d}, J=8.0 \mathrm{~Hz}), 7.35(1$ $\mathrm{H}, \mathrm{dd}, J=2.8,1.6 \mathrm{~Hz}), 6.77(1 \mathrm{H}, \mathrm{dd}, J=1.6,1.2 \mathrm{~Hz}), 6.21(1$ $\mathrm{H}, \mathrm{m}), 2.29$ (3 H, s), $1.63(9 \mathrm{H}, \mathrm{s}) ;{ }^{13} \mathrm{C} \mathrm{NMR}\left(\mathrm{CDCl}_{3}, 100 \mathrm{MHz}\right)$ $\delta 169.3,154.1,153.8,146.8,145.0,138.6,136.8,123.7,122.9$, 122.4, 118.7, 114.7, 112.6, 111.4, 92.6, 84.6, 82.7, $27.6(3 \times), 24.3$; FAB-MS calcd for $\mathrm{C}_{21} \mathrm{H}_{21} \mathrm{~N}_{4} \mathrm{O}_{3} 377.2(\mathrm{M}+\mathrm{H})^{+}$, found $\mathrm{m} / z$ 377.2; HRMS calcd for $\mathrm{C}_{21} \mathrm{H}_{21} \mathrm{~N}_{4} \mathrm{O}_{3} 377.1614(\mathrm{M}+\mathrm{H})^{+}$, found $\mathrm{m} / \mathrm{z}$ 377.2003.

2-Acetamido-7-(1H-pyrrol-2-yl)ethynyl-1,8-naphthyridine (1). Compound 1-Boc (119 mg, $0.3 \mathrm{mmol})$ was dissolved in DMF (5 $\mathrm{mL}$ ), then the solution was heated at $110{ }^{\circ} \mathrm{C}$ for $5 \mathrm{~h}$. The solution was cooled, poured into water, then extracted with EtOAc. The organic layer was washed with water, dried over $\mathrm{Na}_{2} \mathrm{SO}_{4}$, and concentrated in vacuo. The crude material was purified by column chromatography with $\mathrm{MeOH} / \mathrm{CH}_{2} \mathrm{Cl}_{2}$ (1:19) to afford compound 1 (65 mg, 78\% yield).

$\mathrm{C}_{16} \mathrm{H}_{12} \mathrm{~N}_{4} \mathrm{O}: \mathrm{UV}-$ vis $\lambda_{\max }\left(\mathrm{CH}_{2} \mathrm{Cl}_{2}\right) 382 \mathrm{~nm}\left(\epsilon=45000 \mathrm{M}^{-1}\right.$ $\left.\mathrm{cm}^{-1}\right)$; FL $\lambda_{\max }\left(\mathrm{CH}_{2} \mathrm{Cl}_{2}\right) 460 \mathrm{~nm} ;{ }^{1} \mathrm{H} \mathrm{NMR}\left(\mathrm{CDCl}_{3}, 400 \mathrm{MHz}\right) \delta$ $8.91(1 \mathrm{H}, \mathrm{br} \mathrm{s}), 8.76(1 \mathrm{H}, \mathrm{s}), 8.47(1 \mathrm{H}, \mathrm{d}, J=8.0 \mathrm{~Hz}), 8.12(1$ $\mathrm{H}, \mathrm{d}, J=8.0 \mathrm{~Hz}), 8.05(1 \mathrm{H}, \mathrm{d}, J=8.0 \mathrm{~Hz}), 7.48(1 \mathrm{H}, \mathrm{d}, J=8.0$ $\mathrm{Hz}), 6.88(1 \mathrm{H}, \mathrm{dd}, J=2.8,1.6 \mathrm{~Hz}), 6.69(1 \mathrm{H}, \mathrm{dd}, J=1.6,1.2$ $\mathrm{Hz}), 6.25(1 \mathrm{H}, \mathrm{m}), 2.28(3 \mathrm{H}, \mathrm{s}) ;{ }^{13} \mathrm{C} \mathrm{NMR}\left(\mathrm{CDCl}_{3}, 100 \mathrm{MHz}\right) \delta$ $170.0,154.5,154.4,145.9,139.0,137.2,122.9,122.0,118.8,116.6$, 114.7, 110.2, 90.8, 85.2, 24.3; HRMS calcd for $\mathrm{C}_{16} \mathrm{H}_{13} \mathrm{~N}_{4} \mathrm{O}$ $277.1089(\mathrm{M}+\mathrm{H})^{+}$, found $\mathrm{m} / z$ 277.1030.

2-Acetamido-7-(2-aminophenyl)ethynyl-1,8-naphthyridine (3). A Sonogashira coupling reaction of 2-acetamido-7-chloro-1,8naphthyridine $(612 \mathrm{mg}, 2.8 \mathrm{mmol})$ with 2-ethynylaniline $(320 \mathrm{mg}$, 
$2.7 \mathrm{mmol}$ ) in DMF solution was carried out, by a procedure similar to that for 1-Boc, to give compound 3 (609 $\mathrm{mg}$ ) in $75 \%$ yield.

$\mathrm{C}_{18} \mathrm{H}_{14} \mathrm{~N}_{4} \mathrm{O}$ : yellowish solid recrystallized from $\mathrm{MeOH} / \mathrm{H}_{2} \mathrm{O}$, mp $258{ }^{\circ} \mathrm{C}$; TLC $\left(\mathrm{MeOH} / \mathrm{CH}_{2} \mathrm{Cl}_{2}(1: 99)\right) R_{\mathrm{f}} 0.15$; UV-vis $\lambda_{\max }\left(\mathrm{CH}_{2-}\right.$ $\left.\mathrm{Cl}_{2}\right) 377 \mathrm{~nm}\left(\epsilon=24700 \mathrm{M}^{-1} \mathrm{~cm}^{-1}\right) ; \lambda_{\max }(\mathrm{DMSO}) 386 \mathrm{~nm}(\epsilon=$ $\left.14900 \mathrm{M}^{-1} \mathrm{~cm}^{-1}\right), 353 \mathrm{~nm}\left(\epsilon=11800 \mathrm{M}^{-1} \mathrm{~cm}^{-1}\right)$; IR (KBr) 3450, 2194, 1710, $1613 \mathrm{~cm}^{-1} ;{ }^{1} \mathrm{H}$ NMR $\left(\mathrm{CD}_{3} \mathrm{COCD}_{3}, 400 \mathrm{MHz}\right) \delta 10.00$ $(1 \mathrm{H}, \mathrm{s}), 8.48(1 \mathrm{H}, \mathrm{d}, J=8.0 \mathrm{~Hz}), 8.34(2 \mathrm{H}, \mathrm{t}, J=8.0 \mathrm{~Hz}), 7.69$ $(1 \mathrm{H}, \mathrm{d}, J=8.0 \mathrm{~Hz}), 7.38(1 \mathrm{H}, \mathrm{d}, J=8.0 \mathrm{~Hz}), 7.17(1 \mathrm{H}, \mathrm{t}, J=$ $8.0 \mathrm{~Hz}), 6.83(1 \mathrm{H}, \mathrm{d}, J=8.0 \mathrm{~Hz}), 6.63(1 \mathrm{H}, \mathrm{t}, J=8.0 \mathrm{~Hz}), 5.42$ $\left(2 \mathrm{H}, \mathrm{s}, \mathrm{ArNH}_{2}\right), 2.29(3 \mathrm{H}, \mathrm{s}) ;{ }^{13} \mathrm{C} \mathrm{NMR}\left(\mathrm{CD}_{3} \mathrm{COCD}_{3}, 100 \mathrm{MHz}\right)$ o $169.9,155.1,154.9,150.8,146.8,139.1,137.4,132.7,131.2$, 123.8, 119.8, 116.7, 115.3, 114.6, 105.2, 94.9, 89.1, 24.7; HRMS calcd for $\mathrm{C}_{18} \mathrm{H}_{15} \mathrm{~N}_{4} \mathrm{O} 303.1240(\mathrm{M}+\mathrm{H})^{+}$, found $\mathrm{m} / \mathrm{z} 303.1219$. Anal. Calcd: C, 71.51; H, 4.67; N, 18.53. Found: C, 71.17; H, $4.88 ; \mathrm{N}, 18.80$.

2-Acetamido-7-(2-acetamidophenyl)ethynyl-1,8-naphthyridine (3-Ac). Compound $3(50 \mathrm{mg}, 0.2 \mathrm{mmol})$ was treated with acetic anhydride $(15 \mathrm{~mL})$ and $\mathrm{Et}_{3} \mathrm{~N}(15 \mathrm{~mL})$ at $25^{\circ} \mathrm{C}$ for $8 \mathrm{~h}$. The solid products were filtered and rinsed with $\mathrm{Et}_{2} \mathrm{O}$ to give $\mathbf{3}$ - $\mathbf{A c}$ (49 $\mathrm{mg}$ ) in $86 \%$ yield.

$\mathrm{C}_{20} \mathrm{H}_{16} \mathrm{~N}_{4} \mathrm{O}_{2}$ : colorless solid, mp $246{ }^{\circ} \mathrm{C}$; TLC $\left(\mathrm{MeOH} / \mathrm{CH}_{2} \mathrm{Cl}_{2}\right.$ (2.5:97.5)) $R_{\mathrm{f}} 0.12$; UV-vis $\lambda_{\max }\left(\mathrm{CH}_{2} \mathrm{Cl}_{2}\right) 370 \mathrm{~nm}(\epsilon=30100$ $\left.\mathrm{M}^{-1} \mathrm{~cm}^{-1}\right), 356 \mathrm{~nm}\left(\epsilon=29000 \mathrm{M}^{-1} \mathrm{~cm}^{-1}\right) ; \lambda_{\max }(\mathrm{DMSO}) 370$ $\mathrm{nm}\left(\epsilon=35200 \mathrm{M}^{-1} \mathrm{~cm}^{-1}\right), 358 \mathrm{~nm}\left(\epsilon=34100 \mathrm{M}^{-1} \mathrm{~cm}^{-1}\right)$; fluorescence $\lambda_{\max }\left(\mathrm{CH}_{2} \mathrm{Cl}_{2}\right) 407 \mathrm{~nm} ; \lambda_{\max }(\mathrm{DMSO}) 428 \mathrm{~nm}$; IR (KBr) 2209, 1680, $1579 \mathrm{~cm}^{-1} ;{ }^{1} \mathrm{H} \mathrm{NMR}\left(\mathrm{CDCl}_{3}, 400 \mathrm{MHz}\right) \delta 8.73$ $(1 \mathrm{H}, \mathrm{s}), 8.53(1 \mathrm{H}, \mathrm{d}, J=8.0 \mathrm{~Hz}), 8.42(1 \mathrm{H}, \mathrm{d}, J=8.0 \mathrm{~Hz}), 8.17$ $(2 \mathrm{H}, \mathrm{m}), 8.13(1 \mathrm{H}, \mathrm{d}, J=8.0 \mathrm{~Hz}), 7.56(2 \mathrm{H}, \mathrm{dd}, J=8.0 \mathrm{~Hz})$, $7.41(1 \mathrm{H}, \mathrm{t}, J=8.0 \mathrm{~Hz}), 7.09(1 \mathrm{H}, \mathrm{t}, J=8.0 \mathrm{~Hz}), 2.31(3 \mathrm{H}, \mathrm{s})$, $2.30(3 \mathrm{H}, \mathrm{s}) ;{ }^{13} \mathrm{C} \mathrm{NMR}\left(\mathrm{CDCl}_{3}, 100 \mathrm{MHz}\right) \delta 168.9,168.3,154.0$, $153.8,145.6,139.5,138.7,136.6,132.1,130.6,123.5,123.2,119.7$ (2×), 115.4, 110.4, 95.5, 86.6, $25.4(2 \times)$; HRMS calcd for $\mathrm{C}_{20} \mathrm{H}_{17} \mathrm{~N}_{4} \mathrm{O}_{2} 345.1346(\mathrm{M}+\mathrm{H})^{+}$, found $m / z$ 345.1468.

2-Acetamido-7-[2-(methylamino)phenyl]ethynyl-1,8-naphthyridine (3-Me). A Sonogashira coupling reaction of 2-acetamido7-chloro-1,8-naphthyridine (836 mg, $3.8 \mathrm{mmol}$ ) with 2-ethynyl- $\mathrm{N}$ methylaniline (390 mg, $3.0 \mathrm{mmol}$ ) in DMF solution was carried out, by a procedure similar to that for 1-Boc, to give compound 3-Me (440 mg) in $47 \%$ yield.

$\mathrm{C}_{19} \mathrm{H}_{16} \mathrm{~N}_{4} \mathrm{O}$ : yellowish solid recrystallized from acetone, mp $227.4{ }^{\circ} \mathrm{C}$; TLC $\left(\mathrm{MeOH} / \mathrm{CH}_{2} \mathrm{Cl}_{2}(1: 99)\right) R_{\mathrm{f}} 0.15 ; \lambda_{\max }\left(\mathrm{CH}_{2} \mathrm{Cl}_{2}\right) 399$ $\mathrm{nm}\left(\epsilon=17500 \mathrm{M}^{-1} \mathrm{~cm}^{-1}\right), 350 \mathrm{~nm}\left(\epsilon=18100 \mathrm{M}^{-1} \mathrm{~cm}^{-1}\right) ; \lambda_{\max }$ (DMSO) $402 \mathrm{~nm}\left(\epsilon=23900 \mathrm{M}^{-1} \mathrm{~cm}^{-1}\right), 353 \mathrm{~nm}(\epsilon=22400$ $\left.\mathrm{M}^{-1} \mathrm{~cm}^{-1}\right)$; fluorescence $\lambda_{\max }\left(\mathrm{CH}_{2} \mathrm{Cl}_{2}\right) 518 \mathrm{~nm} ; \lambda_{\max }$ (DMSO) 565 $\mathrm{nm}$; IR (KBr) 2200, 1691, $1612 \mathrm{~cm}^{-1} ;{ }^{1} \mathrm{H} \mathrm{NMR}\left(\mathrm{CDCl}_{3}, 400 \mathrm{MHz}\right)$ $\delta 9.96(1 \mathrm{H}, \mathrm{s}), 8.51(1 \mathrm{H}, \mathrm{d}, J=8.0 \mathrm{~Hz}), 8.12(1 \mathrm{H}, \mathrm{d}, J=8.0$ $\mathrm{Hz}), 8.03(1 \mathrm{H}, \mathrm{d}, J=8.0 \mathrm{~Hz}), 7.50(1 \mathrm{H}, \mathrm{d}, J=8.0 \mathrm{~Hz}), 7.40(1$ $\mathrm{H}, \mathrm{d}, J=8.0 \mathrm{~Hz}), 7.27(1 \mathrm{H}, \mathrm{t}, J=8.0 \mathrm{~Hz}), 6.63(1 \mathrm{H}, \mathrm{t}, J=8.0$
$\mathrm{Hz}), 6.58(1 \mathrm{H}, \mathrm{d}, J=8.0 \mathrm{~Hz}), 2.91(3 \mathrm{H}, \mathrm{s}), 2.34(3 \mathrm{H}, \mathrm{s}) ;{ }^{13} \mathrm{C}$ $\mathrm{NMR}\left(\mathrm{CDCl}_{3}, 100 \mathrm{MHz}\right) \delta 169.7,154.1,153.9,150.2,146.2,138.5$, 136.1, 132.4, 131.0, 123.4, 119.1, 115.7, 115.5, 108.8, 105.0, 95.0, 89.0, 30.4, 25.4; HRMS calcd for $\mathrm{C}_{19} \mathrm{H}_{17} \mathrm{~N}_{4} \mathrm{O} 317.1397(\mathrm{M}+\mathrm{H})^{+}$, found $\mathrm{m} / \mathrm{z} 317.1462$.

UV-Vis Titration Studies. The stock solutions of receptor compound (e.g., 3-Me, $\left.1 \times 10^{-5} \mathrm{M}\right)$ and 9-alkylguanine $\left(1 \times 10^{-2}\right.$ $\mathrm{M})$ were prepared by using spectroscopic grade dichloromethane. The stock solution $(2 \mathrm{~mL})$ of receptor compound was placed in a quartz cell ( $1 \mathrm{~cm}$ length), and the absorption spectrum was recorded at $298 \mathrm{~K}$. The stock solution of alkylguanine was introduced in an incremental fashion ( $2 \mu \mathrm{L}$ corresponds to 1.0 equiv); the mixture was shaken well, and the corresponding UV-vis curves were recorded.

Fluorescent Titration Studies. The fluorescence spectra were taken by using the same samples employed in the UV-vis study, i.e., transferring the same cuvette from the UV-vis spectrophotometer to the fluorescence spectrophotometer for each incremental addition. The fluorescence spectra, obtained by excitation at the absorption isosbestic point, were taken as a function of the concentrations of alkylguanine.

On the basis of the 1:1 stoichiometry of the complex, the binding constant was calculated according to the following equation, and determined by the nonlinear least-squares curve fitting method.

$$
y=f+[(d-f) /(2 c)]\left\{K^{-1}+c+x-\left[\left(K^{-1}+c+x\right)^{2}-4 c x\right]^{0.5}\right\}
$$

where $c$ is the receptor concentration, $d$ is the maximum change of fluorescence intensity at saturation, $f$ is the initial fluorescence intensity, $K$ is the association constant, $x$ is the substrate concentration, and $y$ is the fluorescence intensity.

ESI-MS Analysis. A mixture of receptor molecule (3-Ac or 3-Me) and decylguanine in a 1:1 molar ratio was dissolved in $\mathrm{CH}_{2}$ $\mathrm{Cl}_{2}$, and the solvent was then removed under reduced pressure. The residue was diluted to ca. $1 \mu \mathrm{M}$ in aqueous $\mathrm{CH}_{3} \mathrm{CN}(50 \%)$ containing 0.15 equiv of $\mathrm{HOAc}$, which was also used as the spray solvent for MS analysis.

Acknowledgment. We thank the National Science Council for financial support and Mr. Yi-Ming Cheng (Department of Chemistry, National Taiwan University) for molecular computation.

Supporting Information Available: Preparation procedures, compound characterization, NMR, UV-vis, fluorescence, ESIMS spectra, Job's plots, and molecular computation. This material is available free of charge via the Internet at http://pubs.acs.org.

JO061831B 